\title{
Fixed Prosthodontics - 15 Teeth Block In Non-Metal Ceramic
}

\author{
Milan Pavlovic* \\ Specialist in periodontology and oral medicine, free ceramics, implants, Dentikum, Serbi ${ }^{a}$
}

Submission: : November 17, 2016; Published: November 30, 2016

*Corresponding author: Milan Pavlovic, Dentist, Specialist in periodontology and oral medicine, free ceramics, implants, Dentikum, Serbia, Makedonska 21, 11000 Beograd, Tel: +38163218520; Email: office@drmilanpavlovic.com

\section{Power Presentation}

Prosthetic rehabilitation and reconstruction, the whole jaw, all 14 teeth without adjusting. That this did need the following: a clear vision of what it wants to do and how (working plan).

1. Carefully first grinding:

A. What teeth, how much needs to be shortened.

B. And how much should be ground to achieve parallel.

C. Control parallel is achieved, are what we approximate footprint, and we are trying to spotlight, we find the position, when can we see lit, complete interior grinding. Parts that are in the shade, not in parallel, and they need not grind. The procedure must be repeated until the desired results.

2. Clear and precise imprint

3. Agreement with a technician

A. Do not make any correction model (technician not to touch model)

B. In as much as there are irregularities need to repeat the previous process (grinding and print).

C. In the model and in consultation with the technician clearly formulate the problem and the way to solve the problem.

4. Try all phases of work

5. Rehearsal ceramics, and aligns the dental stump, as it bite, among the tooth spaces, the line of teeth, angle and arc tooth

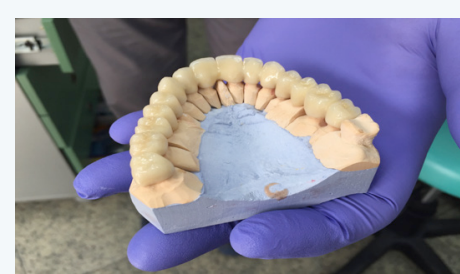

Figure 1
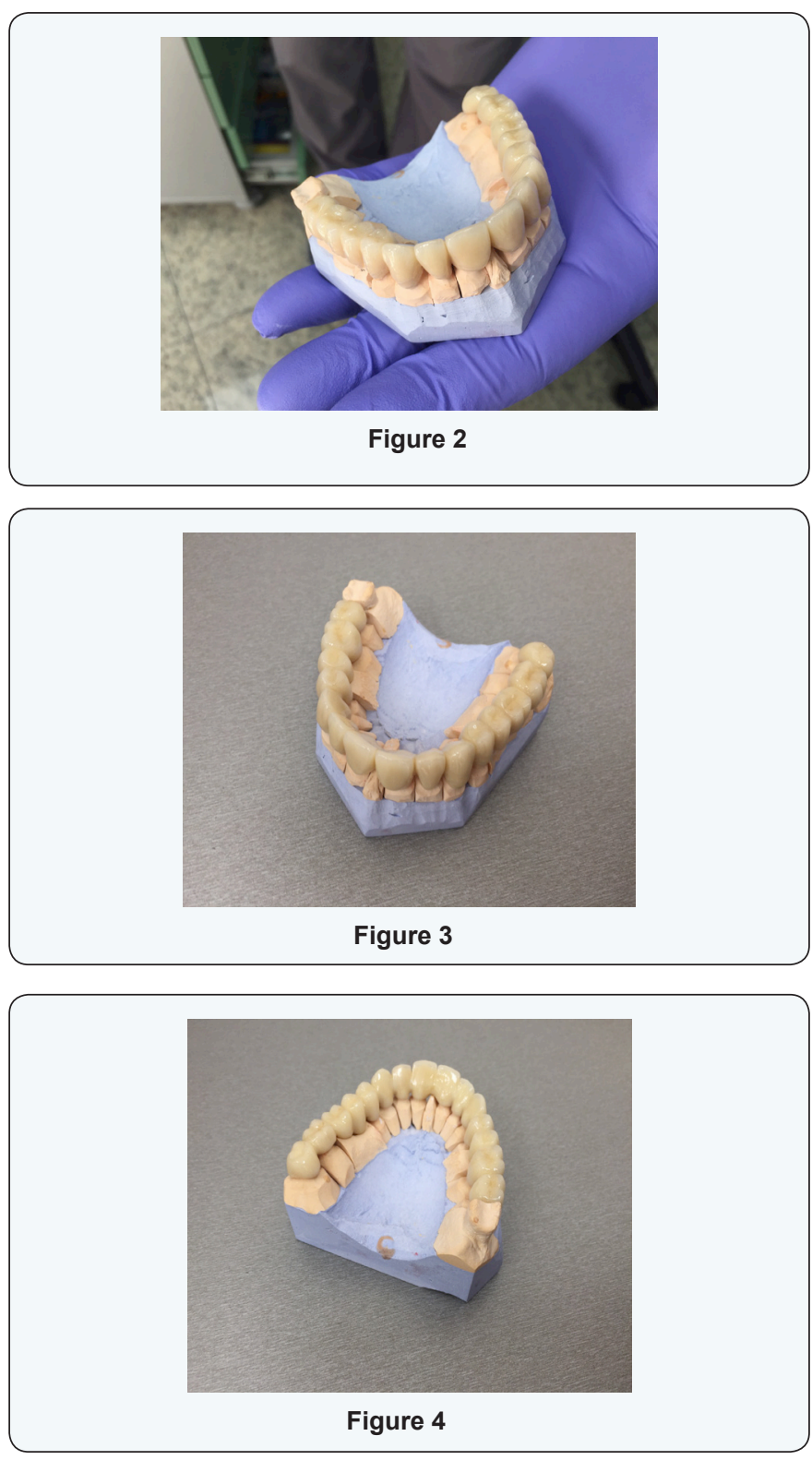

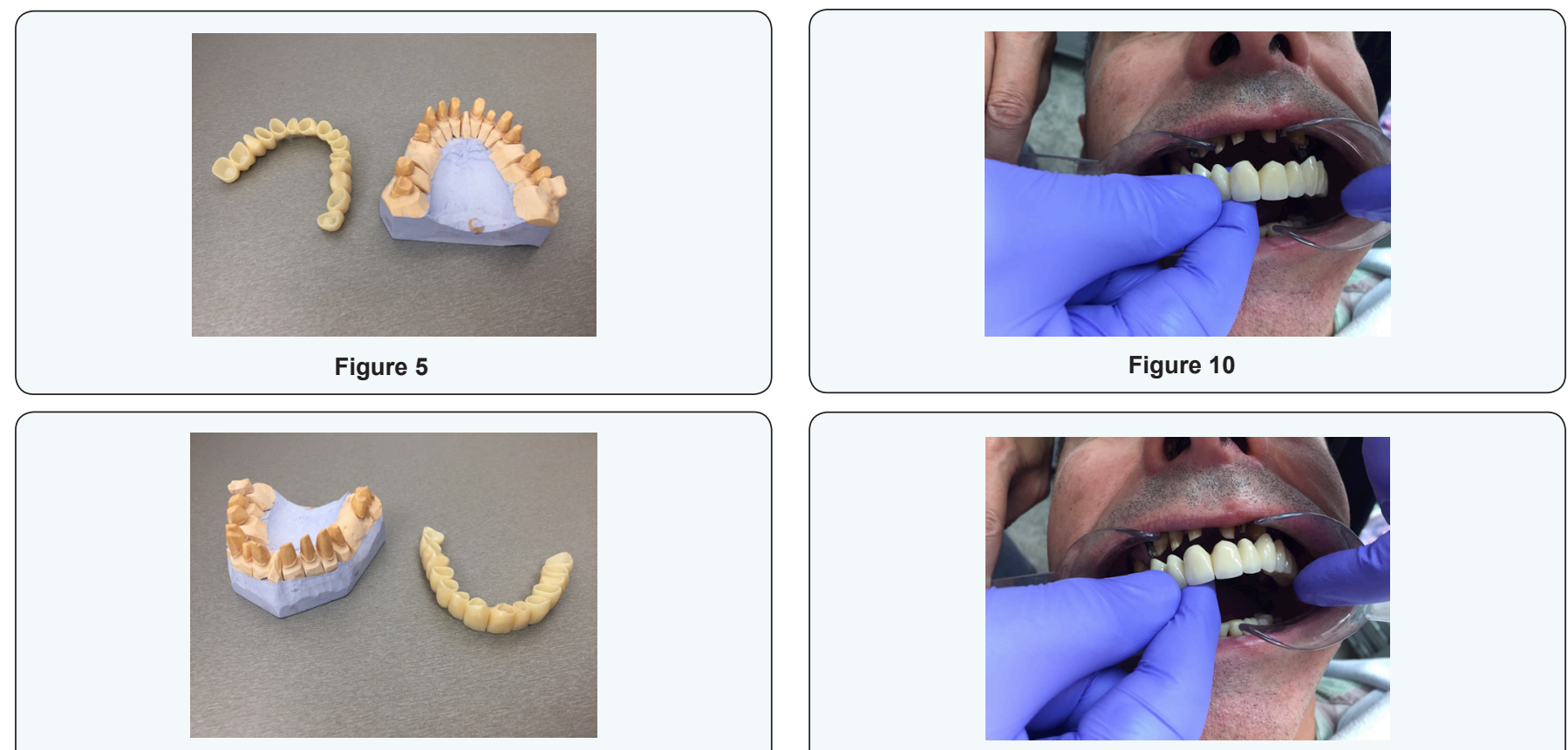

Figure 6

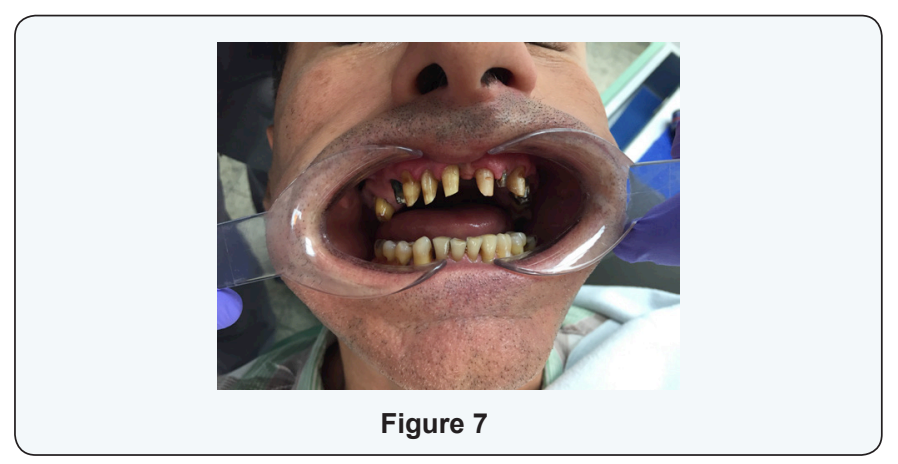

Figure 7

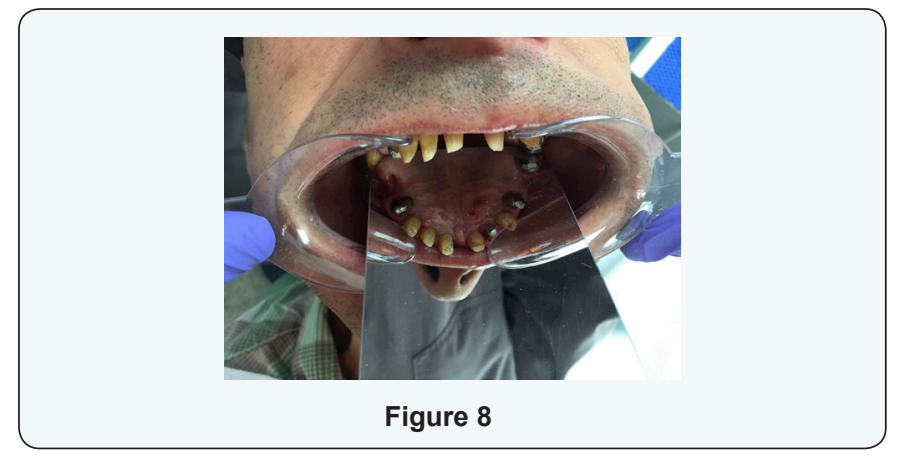

Figure 8
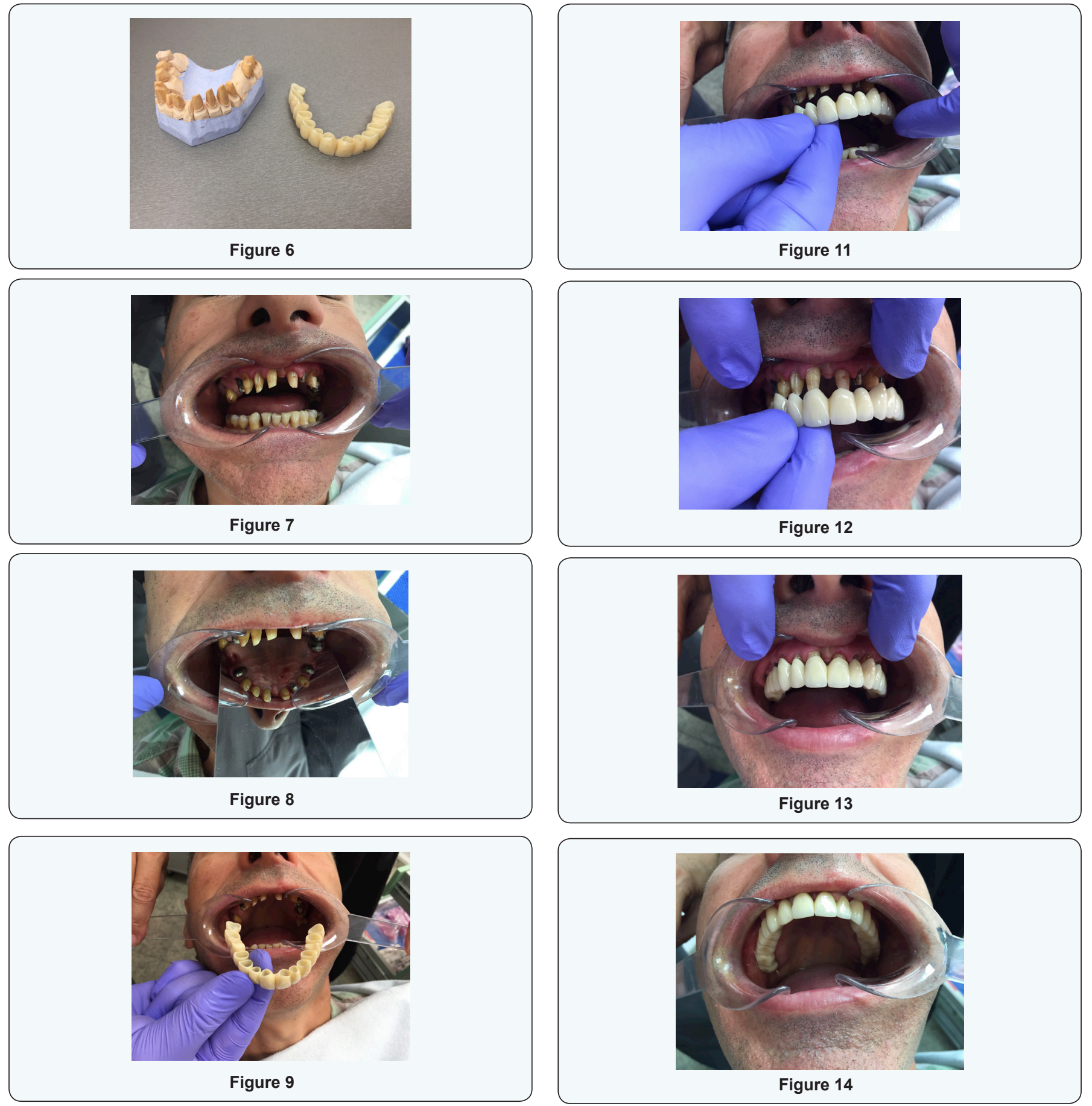


\section{Advances in Dentistry \& Oral Health}

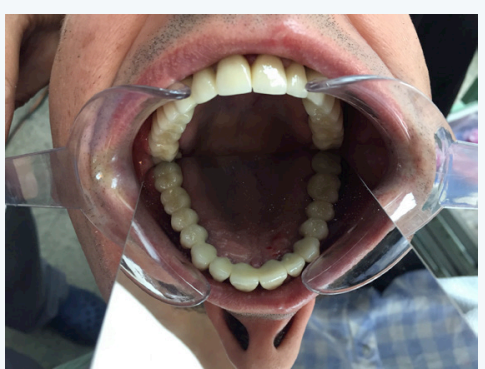

Figure 15

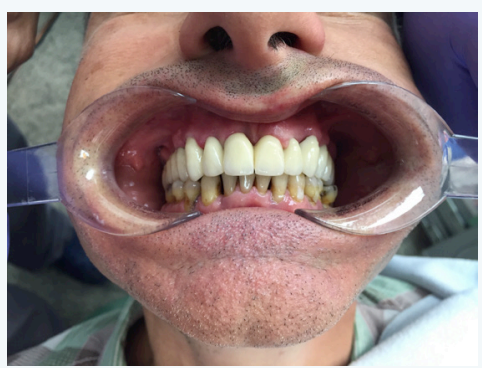

Figure 16

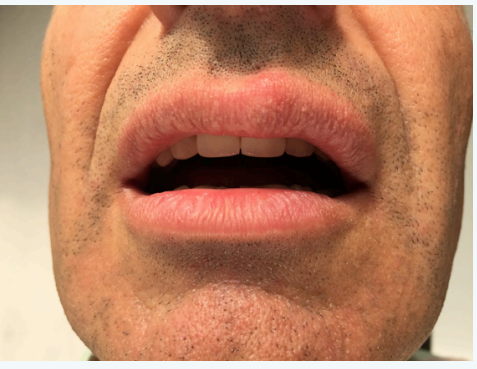

Figure 17

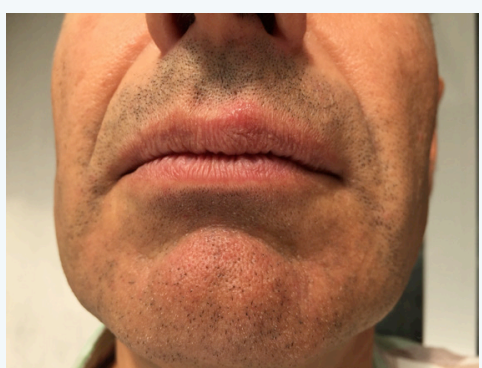

Figure 18
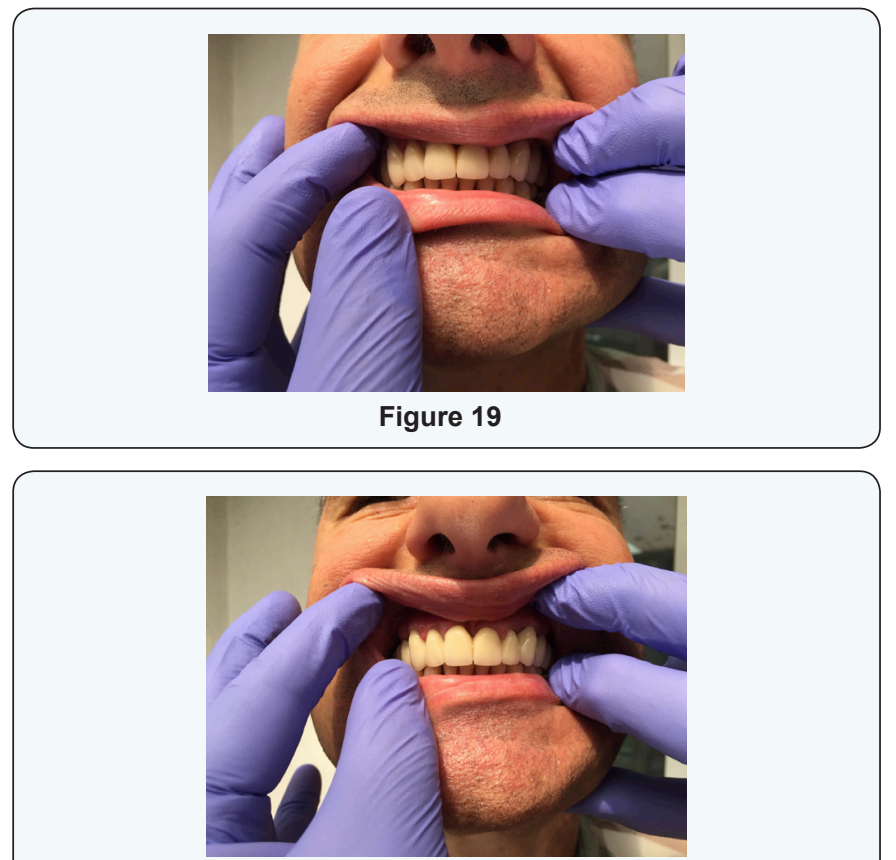

Figure 20
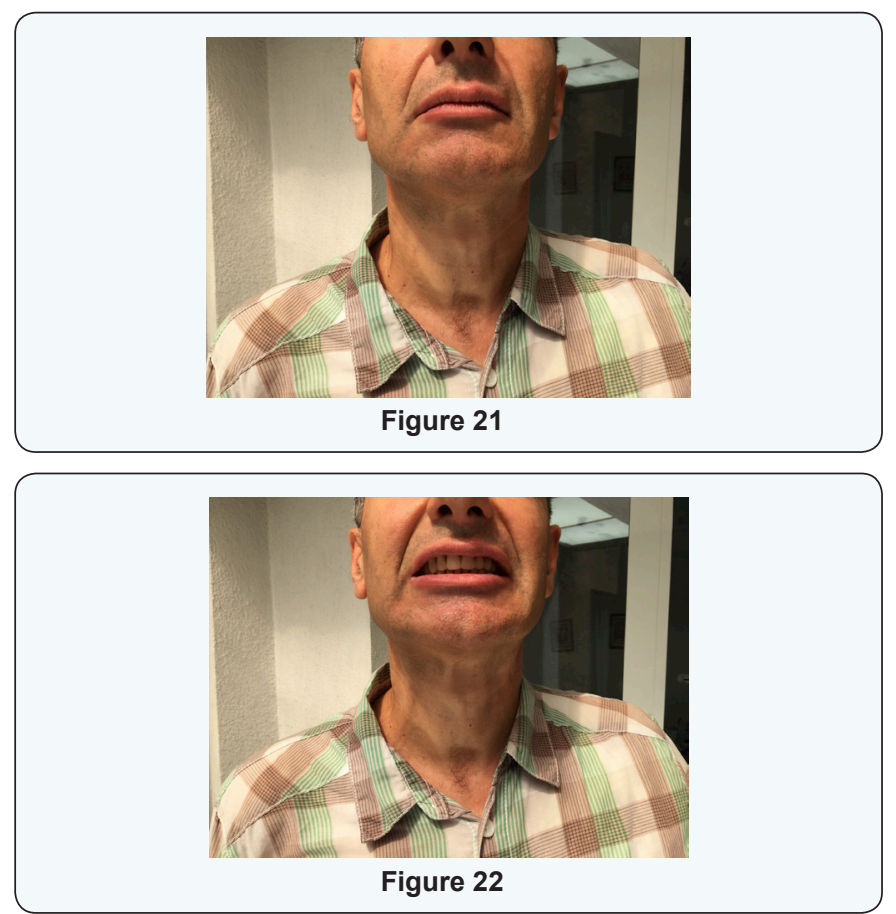

Figure 22

\footnotetext{
Your next submission with JuniperPublishers will reach you the below assets

- Quality Editorial service

- Swift Peer Review

- Reprints availability

- E-prints Service

- Manuscript Podcast for convenient understanding

- Global attainment for your research

- Manuscript accessibility in different formats

(Pdf, E-pub, Full Text, Audio)

- Unceasing customer service
}

Track the below URL for one-step submission

http://juniperpublishers.com/online-submission.php 